\title{
Refractory Lung Small Cell Carcinoma
}

National Cancer Institute

\section{Source}

National Cancer Institute. Refractory Lung Small Cell Carcinoma. NCI Thesaurus. Code C150581.

Small cell lung carcinoma that does not respond to treatment. 